\title{
Poisoning by the ingestion of seeds of the fruit of the "cotieira" (Joannesia princeps).
}

Biomedic Science Center, Universidade Federal de Uberlândia - Minas Gerais, Brazil

A 15-year-old boy ingested the core of two seeds of a fruit of Joannesia princeps, a large tree sometimes found planted in sidewalks on streets in Brazilian towns. Four hours after the ingestion, he had several episodes of vomiting and diarrhea, but recovered spontaneously th same day. Poisoning by the ingestion of seeds of Joannesia princeps is possibly not rare, considering that the tree gives plenty of fruit and the seeds have an agreeable flavor, but is probably underestimated as mild cases are unlikely to be reported. Ingestion by small children, that could lead to potentially more severe cases, is in part probably prevented by the hardness of the shells covering the seeds.

UNITERMS: Fruit, joannesia princeps, poisoning, plant, seeds

\section{CASE REPORT}

1 15-year-old boy ingested the core of two seeds of a dried fruit he found in his backyard. He denied having done that before, but he knew the fruit by the name of "castanheira." Four hours later he had several episodes of vomiting and diarhea and sought medical assistance at the emergency Room of the university hospital in Uberlândia, where he arrived 8 hours after the ingestion. At the time he was feeling better, his physical examination was normal, and he was discharged after being oriented about oral rehydration. When contacted one week later, the patient said that his symptoms had disappeared on the same day.

The fruit he ate had been taken home months before, from a tree in the neighborhood by his father, who intended to plant it because it provides good shade.

\section{Address for correspondence:}

Sérgio de Andrade Nishioka

Av. Teresina, 1415 - Umuarama

Uberlândia/MG - Brasil - CEP 38405-384
The boy said that the seeds had a flavor resembling that of peanuts. Fruit and leaves from the same tree were recovered and identified as Joannesia princeps.

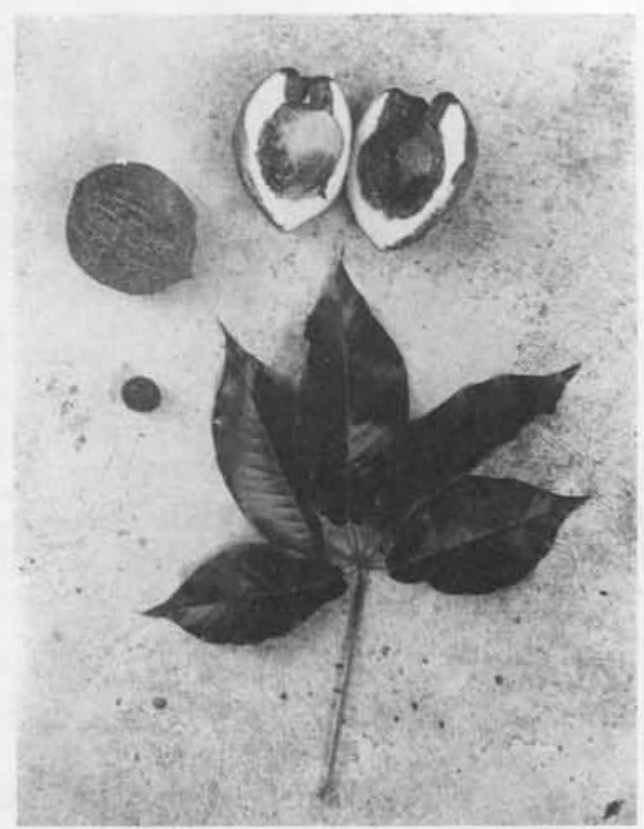

Figure 1 - Poisoning by the ingestion of seeds of the fruit of the cotieira. 


\section{DISCUSSION}

Joannesia princeps, known in parts of Brazil as "cotieira," is a tree of the family Euphorbiaceae which reaches a large size, has a straight stem, and gives large fruits with 2 or 3 egg-shaped seeds. The seed have an oil with strong purgative action. ${ }^{1}$

Trees of the species Joannesia princeps are sometimes planted on sidewalks in the urban area of Brazilian towns. In Uberlândia, around 300 trees of this species were once planted, because of their rapid growth and large shadow, but most were cut years later after the realization that they represented a hazard because of falling branches due to their soft heartwood, and also because some cases ofmild poisoning were reported (Mr. Geraldo Rocha Novaes, from the Horto Municipal of Uberlândia, personal communication).

The incidence of poisoning by the seeds of Joannesia princeps is unknown, but poisoning should not be rare considering that the tree gives plenty of fruit, the fruit have an attractive shape, and the seeds have an agreeable flavor. The fact that the seeds are covered by hard shells explains, at least in part, why poisoning by Joannesia princeps is apparently not common. Is is also possibly underreported because in mild cases victims probably do not seek medical assistance. Even if not life threatening, ingestion of the seeds can be a hazard, particularly to children, due to possible dehydration and electrolyte disturbances. ${ }^{2}$

Although our patient had mild poisoning, we believe that it is important to regster the case as a source of information for physicians working in toxicologic information centers, because of the scarcity of information on clinical aspects of Joannesia princeps poisoning.

Trees, shrubs and plant for streets and public gardens should not be poisonous or, at least, warning should be given to avoid poisoning by inadvertent ingestion of fruits and other parts of them.

\section{ACKNOWLEDGMENT}

To Ivan Schiavini, Professor of Botany at the Universidade Federal de Uberlândia, who identified the specimens.

\section{Resumo}

Um jovem de 15 anos de idade ingeriu o interior de duas sementes de um fruto de Joannesia princeps, uma árvore frondosa não raramente utilizada na arborização de cidades brasileiras. Após 4 horas de ingestão o paciente apresentou diversos episódios de vômito e diarréia, mas recuperou-se espontaneamente no mesmo dia. $O$ envenenamento pela ingestāo de sementes de Joannesia princeps pode ser mais comum do que se pensa, considerando o fato de que a árvore produz muitos frutos, e que as sementes têm um sabor agradável, lembrando o do amendoim; o número de casos deve ser subestimado em funçẩo de serem eles, em geral, leves e autolimitados. A ingestão por parte de crianças, potencialmente mais grave, é provavelmente em parte prevenida pelo fato do fruto ser consistente e as sementes, portanto, de dificil acesso. Nāo é recomendảvel que se utilizem árvores, arbustos e outras plantas venenosas para ornamentação em vias e jardins públicos.

\section{REFERENCES}

1. Pio-Correa M. Dicionário das Plantas úteis do Brasil e das Exóticas Cultivadas, Vol. I. Rio de Janeiro, Imprensa Nacional, 1926:111-113.

2. Schvartsman S.S. Plantas Venenosas. São Paulo: Sarvier 1979:87. 